\title{
Międzynarodowa Konferencja Naukowa „Higher Education Advances (HEAd'15)" (Walencja, 24-26 czerwca 2015 r.)
}

W dniach 24-26 czerwca 2015 roku w nowoczesnym gmachu Faculty of Business Administration and Management - jednym z wydziałów Universitat Politècnica de València ${ }^{1}$ - odbyła się Międzynarodowa Konferencja Naukowa „Higher Education Advances (HEAd'15)”. W przygotowaniu spotkania, oprócz pracowników Universitat Politècnica de València (przewodniczący Komitetu Organizacyjnego Josep Domènech), uczestniczyli przedstawiciele: University of Michigan-Dearborn, Singidunum University, University of Koya, Centro de Formación Tecnológica de ADIF. W międzynarodowym Komitecie Programowym zasiedli również pracownicy polskich uczelni: Katarzyna Anna Kuźmicz z Politechniki Białostockiej, Maciej Laskowski z Politechniki Lubelskiej i Aleksandra Kulpa-Puczyńska z Uniwersytetu Kardynała Stefana Wyszyńskiego w Warszawie, która brała aktywny udział w konferencji, będąc przewodniczącą jednej z sekcji tematycznych „Entrepreneurship” oraz wygłaszając referat pt. The model of cooperation with employers as the support measure for the development of entrepreneurial university potential. Celem wystapienia było przedstawienie wybranego modelu współpracy z pracodawcami, rozwiązania wprowadzonego przez UKSW, a także zwrócenie uwagi na możliwości rozwoju potencjału przedsiębiorczego uniwersytetu na przykładzie m.in. Wydziału Nauk Pedagogicznych ${ }^{2}$.

Podczas trzydniowego spotkania w jednej z najlepszych uczelni technicznych w Hiszpanii analizowano (w ramach trzech sesji plenarnych, siedmiu sekcji tematycznych oraz sesji plakatowej) kwestie związane z różnymi aspektami działalności szkół wyższych: planowaniem i organizacją procesu kształcenia oraz oceną jego efektów, doskonaleniem zawodowym nauczycieli i kształceniem przyszłych dydaktyków, innowacyjnymi metodami nauczania, zastosowaniem nowoczesnych technologii w praktyce edukacyjnej, zdobywaniem wiedzy przez studentów

\footnotetext{
${ }^{1}$ http://www.upv.es/entidades/ADE/index-en.html (otwarty 14.07.2015).

${ }^{2}$ http://ocs.editorial.upv.es/index.php/HEAD/HEAD15/paper/view/435 (otwarty 14.07.2015).
} 
i rozwijaniem ich umiejętności poza salami dydaktycznymi, sposobami dostosowania edukacji do zmieniających się potrzeb gospodarki i rynku pracy oraz współpracą uczelni z pracodawcami. Wymienione zagadnienia nie zamykają listy omawianych problemów. Koncentrowano się na wymianie nie tylko poglądów teoretycznych, ale przede wszystkim doświadczeń odnoszących się do różnych dziedzin i dyscyplin naukowych: humanistycznych (filozofia, językoznawstwo), społecznych (nauki o mediach, pedagogika), ekonomicznych (ekonomia, nauki o zarządzaniu) oraz nauk medycznych. Specjalistyczną wiedzą i tzw. dobrymi praktykami, również na łamach przygotowywanej publikacji, podzielili się reprezentanci aż 41 krajów, co świadczy o aktualności i ważności tematyki zaproponowanej przez organizatorów tegorocznego spotkania. W trakcie jego trwania przyznano również nagrody za najciekawsze referaty (Daniela Zehetmeier, Axel Böttcher, Anne Brüggemann-Klein, Veronika Thurner - Development of a classification scheme for errors observed in the process of computer programming education), w tym najlepsze wystąpienie studentów (Naina Garg, Eric Lee - Mixed-format exams in higher education: Assessment of internal consistency reliability).

Podczas konferencji z głównymi prezentacjami wystąpili uznani badacze, odnoszący duże sukcesy także w działalności dydaktycznej, zajmujący się m.in. takimi zagadnieniami, jak przedsiębiorczość, komercjalizacja technologii, nabywanie kompetencji zawodowych, zastosowaniem systemów multimedialnych i technologii w edukacji: John Kalu Osiri (Washington State University) z referatem The indispensable role of educators in shaping a nation, Ana Muñoz-Miquel (Universitat Jaume I) - How to bridge the gap between professional practice and university education: A methodological approach, José V. Benlloch-Dualde (Universitat Politècnica de València) z prezentacją Effective ways to enhance collaboration in the classroom. Wymienione referaty były przedmiotem refleksji uczestników obrad oraz licznych pytań zadawanych prelegentom.. Z tematami poszczególnych sekcji towarzyszących spotkaniu w Walencji, jak i problematyką poruszaną w czasie wystąpień oraz w trakcie interesującej sesji plakatowej można zapoznać się na stronie konferencji ${ }^{3}$.

Aleksandra Kulpa-Puczyńska

UKSW, Warszawa

3 http://www.headconf.org/program/ (otwarty 14.07.2015). 